DOI https://doi.org/10.30525/978-9934-588-80-8-1.26

\title{
СОЦІАЛЬНО-ПСИХОЛОГІЧНІ ДЕТЕРМІНАНТИ ПРОФЕСІЙНОГО САМОВИЗНАЧЕННЯ СТУДЕНТІВ-ЕКОНОМІСТІВ У ЗАКЛАДАХ ВИЩОЇ ОСВІТИ
}

\author{
Мартиненко О. О. \\ аспірант кафедри психологіі \\ Київський національний торговельно-економічний університет \\ м. Київ, Україна
}

Проблема професійного самовизначення нині залишається актуальною для студентів закладів вищої освіти (ЗВО). Ї̈̈ складність пов'язана з конкретною економічною ситуацією в країні, динамічністю ринку праці, з виникненням нових професій, ціннісними орієнтаціями i переконаннями суспільства. У зв'язку з цим змінюється ставлення до професії, змістом трудової діяльності і іiі результатами [2, с. 49]. 3 іншого боку, нині існують унікальні можливості для повноцінного i вільного професійного та особистісного самовизначення. Незважаючи на це, вибір закладу вищої освіти і профілю освіти часто визначається не затребуваністю на ринку праці, інтересами i схильностями конкретної особистості, а уявленням про «престиж», «успішність» професії в конкретному суспільстві. Як наслідок, низка соціальнозначущих професій стають незатребуваними, обираються абітурієнтами випадково [4, с. 44].

Підходи до розгляду проблеми професійного самовизначення в основному зводяться доможливості прогнозування напряму професійного вибору, побудови кар'єрних планів,професійних досягнень, особливостей професійної поведінки, задоволеності від професійної діяльності, психологічної готовностідо професійної діяльності.

У межах соціальної психології професійне становлення студентівекономістів розглядається як інтеграція особистості в соціальні інститути і групи [3, с. 57]. На основі аналізу літератури з вивчення професійного становлення студентів визначено соціально-психологічні детермінанти, які впливають на особистість і іiі професійне самовизначення. У межах статті соціально-психологічні детермінанти професійного самовизначення студентів-економістів розглядаємо крізь утворення зовнішніх i внутрішніх впливів в процесі фахової підготовки, які супроводжують i формують успішне професійне становлення студента. 
Значущим чинником професійного становлення особистості $\epsilon$ освітнє середовище. Вона задає умови, які впливають на формування особистості [1, с. 358]. Суспільні умови професійного становлення $є$ сукупністю аспектів, зокрема матеріальних і соціальних позицій особистості, які визначають подальший розвиток студентів-економістів у межах освітнього процесу. Соціальний стан особистості в середовищі $\epsilon$ показником інтерналізації ціннісних пріоритетів, що забезпечує цілісне уявлення життєвих цілей у середовищі ЗВО [5, с. 208]. Соціальне середовище ЗВО впливає на професійне становлення студентів-економістів на основі зовнішніх чинників, серед яких соціально-психологічні характеристики середовища ЗВО. Розглядаючи даний процес, необхідно уточнити, що до соціального середовища 3ВО відноситься педагогічний вплив та міжособистісні відносини в студентській групі. Залежно від цих чинників утворюється соціальнопсихологічний клімат всередовищі, який визначає рівень впливу соціального середовища на процеспрофесійного становлення майбутніх економістів. Він зумовлюється:

1) особливостями взаємодії викладача зі студентом [4];

2) співвідношенням навчання і виховання в процесі підготовки i наявністю психологічного клімату в групі [2];

3) соціальне середовище ЗВО є впливом зовнішніх подразників на учасників освітнього процесу [1].

Відтак, соціальне середовище ЗВО є одним з головних чинників соціально-психологічних детермінант, який утворює соціально-психологічну комфортність особистості в процесі професійного самовизначення. Водночас одним з важливих чинників успішного професійного становлення студентів-економістів визначається адаптованість особистості до соціального середовища. Таким чином, адаптованість студента до соціального середовища виявляється на основі його ідентичності, мотивації до навчання, самооцінки.

Соціально-психологічні чинники, що впливають на процес професійного самовизначення студентів-економістів відображають інтереси, потреби, якості особистості. У межах статті соціально-психологічні детермінанти визначаємо як соціально-психологічні якості студентів, характер міжособистісних відносин і соціально-психологічні характеристики середовища ЗВО. Окреслені детермінанти найповніше відображають особливості організації освітнього процесу. Соціальнопсихологічні якості студентів, сформовані в процесі професійного самовизначення та становлення $\epsilon$ індивідуальними якостями майбутніх економістів, що впливають на ефективність праці. 
Соціально-психологічні якості студентів визначають бажані цінності студентів, сенсожиттєві орієнтації, особистісну значущість соціального мікросередовища, особистісну значущість професійнопедагогічних якостей викладача. Основу ефективного професійного самовизначення майбутніх економістів у середовищі ЗВО вбачаємо у чинників взаємодії викладачів і студентів, а також особливостей соціальних норм $3 \mathrm{BO}$ i його традицій. Як доцільно зазначає В. Лозовецька, навчальне середовище ЗВО вибудовується на звичаях, переконаннях, традиціях, які передаються в формі поведінки i відносин, також формують очікування у всіх викладачів, співробітників і студентів $3 \mathrm{BO}$ [3, с. 57].

Значну частину в процесі професійного самовизначення та становлення студентів-економістів становлять особливості взаємодії викладачів і студентів. В межах аналізу педагогічної взаємодії необхідно враховувати особистісні особливості викладача та рівень їхньої компетентності та оптимального вибору методів навчання. Також соціальні норми і традиції ЗВО розглядаються як зовнішні регулятори поведінки, де ключове значення посідає реалізація ціннісно-смислового потенціалу традицій, що забезпечує стійкість моральної сфери особистості, а також здатність протистояти негативним соціокультурним впливам [5, с. 215].

Таким чином, соціально-психологічними детермінантами професійного самовизначення студентів-економістів у ЗВО визначено соціально-психологічні якості студентів, соціально-психологічна характеристика академічної групи і соціально-психологічні характеристики соціального середовища ЗВО. Не менш важливими соціальнопсихологічними особливостями професійного самовизначення молоддю професії економіста $є$ життєві цінності та збалансованості цінностей гуманістичної і прагматичної спрямованості. Другий чинник представлений функціями самосвідомості, які відповідають за регуляцію поведінки. Третій чинник характеризується особистісними якостями: пристосованістю і екстраверсія; четвертий - представлений мотивом спілкування в процесі навчання в економічних ЗВО.

\section{Література:}

1. Авер'янова А. В. Концептуальні підходи до проблеми професійного самовизначення особистості у вітчизняній та зарубіжній психології. Молодий вчений. 2015. № 2(6). С. 357-360.

2. Закатнов Д. О. Технології підготовки учнівської молоді до професійного самовизначення: монографія. К.: Педагогічна думка. 2012. $160 \mathrm{c}$. 
3. Лозовецька В. Т. Професійна орієнтація молоді в умовах сучасного ринку праці. К.: ІПТО НАПН України, 2012. 157 с.

4. Ошуркевич Н. Генеза та сутнісний зміст професійного самовизначення особистості. Педагогічний процес: теорія і практика. 2018. Вип. 4. С. 43-49.

5. Семенов И. Н., Савенкова И. А. Рефлексивно-психологические аспекты развития и профессионального самоопределения личности. Мир психологии. 2007. № 2. С. 203-216.

DOI https://doi.org/10.30525/978-9934-588-80-8-1.27

\title{
ПСИХОЛОГО-ПЕДАГОГІЧНІ УМОВИ РОЗВИТКУ ПРОФЕСІЙНОЇ ІДЕНТИЧНОСТІ СТУДЕНТІВ ГУМАНІТАРНИХ ФАКУЛЬТЕТІВ У ЗАКЛАДІ ВИЩОЇ ОСВІТИ
}

\author{
Мисник М. О. \\ студентка 2 курсу магістратури факультету психології \\ Київський національний університет імені Тараса Шевченка \\ м. Київ, Украӥна
}

Сучасною особливістю розвитку психологічної та педагогічної наук у вищій школі $є$ їі підвищений інтерес до розробки стратегій рішень прикладних проблем. Таким чином, звертається особлива увага до дослідження процесу освітньо-професійної соціалізації студентів, формування їх професійно важливих якостей та пізнавальних процесів, пошук критеріїв та показників професійного, особистісного, соціального і розумового розвитку, вияв психолого-педагогічні умов розвитку їх професійної ідентичності тощо.

На цій основі здійснюється пошук традиційних та інноваційних освітніх, тренінгових технологій на різних стадіях професіонального становлення студентів і викладачів як суб'єктів освітнього простору та професійної соціалізації вищої школи.

Варто зазначити, університет як соціокультурна система, не є тільки транслятором професійних знань майбутньому фахівцю у певній галузі, a $\epsilon$ середовищем розвитку його професійної ідентичності на всіх етапах навчання. А також виступає фундаментом для формування важливих психічних утворень, які у єдності забезпечують становлення особистості як професіонала та забезпечують їй особистісне та кар'єрне зростання. Таким чином, майбутні фахівці починають усвідомлювати 